Original Article

\title{
COMBINATION OF WHOLE BRAIN RADIOTHERAPY WITH DIFFERENT FRACTION AND CONCOMITANT CAPECITABINE IN BRAIN METASTASIS BREAST CANCER
}

\author{
YEOH RUDIYO ${ }^{1}$, JAPARDI ISKANDAR ${ }^{2}$, LELO AZNAN ${ }^{3}$, SUSWORO SUSWORO ${ }^{4}$, PANDELAKI JACUB ${ }^{7}$, BACHTIAR \\ ADANG $^{5}$, ICHWAN MUHAMMAD ${ }^{3}$, INDHARTY SUZY ${ }^{6}$, JAMNASI JULI ${ }^{1}$, OMAR WILLIAM ${ }^{1}$
}

1Department of Radiotherapy, MurniTeguh Memorial General Hospital, Medan, Indonesia, ${ }^{2}$ Department of Neurosurgery, Siloam General Hospital, Medan, Indonesia, ${ }^{3}$ Department of Pharmacology and Therapeutics, Faculty of Medicine, Universitas Sumatera Utara, Medan, Indonesia, ${ }^{4}$ Department of Radiotherapy, Cipto Mangunkusumo National Central General Hospital, Jakarta, Indonesia, ${ }^{5}$ Faculty of Public Health, University of Indonesia, Jakarta, Indonesia, ${ }^{6}$ Department of Neurosurgery, Haji Adam Malik General Hospital, Medan, Indonesia, ${ }^{7}$ Department of Radiology, CiptoMangunkusumo National Central General Hospital, Jakarta, Indonesia Email: haseojr1@gmail.com

Received: 20 Jan 2020, Revised and Accepted: 19 Mar 2020

\section{ABSTRACT}

Objective: Breast cancer is the second most frequent cancer worldwide. The main therapeutic modality for breast cancer with brain metastasis is radiation. Whole Brain Radiotherapy (WBRT) is a regional treatment that provides moderate doses of radiotherapy to all brain tissue. Capecitabine was found to be effective for the treatment of breast cancer with metastasis. This study aims to determine the effectiveness of WBRT on the response of breast cancer brain metastatic lesions combined with capecitabine administration.

Methods: This study uses a prospective, randomized-blind cohort analytic study approach. Subjects were randomized into two groups by giving different fraction of WBRT and capecitabine. Subjects were evaluated $4 \mathrm{w}$ post-radiation. Data on differences in patient responses in the two treatment groups were analyzed.

Results: A total of 23 breast cancer patients with brain metastasis participated in this study. Group I (WBRT 10x3Gy + capecitabine 1000 $\mathrm{mg} / \mathrm{m} 2 / \mathrm{b}$.i.d) obtained results of 5 (45.5\%) out of 11 are responding to therapy. Whereas in group II (WBRT 20x2Gy + capecitabine1000 $\mathrm{mg} / \mathrm{m} 2 / \mathrm{b}$.i.d) found $11(91.7 \%)$ out of 12 patients responded to therapy. The results of statistical analysis showed that there were significant differences between the two groups with a value of $\mathrm{P}=0.027$.

Conclusion: Giving capecitabine and WBRT with 20x2Gy gives a better response both clinically and statistically

Keywords: WBRT, Capecitabine, Breast cancer, Brain metastases

(C) 2020 The Authors. Published by Innovare Academic Sciences Pvt Ltd. This is an open access article under the CC BY license (http://creativecommons.org/licenses/by/4.0/) DOI: http://dx.doi.org/10.22159/ijcpr.2020v12i3.38316. Journal homepage: https://innovareacademics.in/journals/index.php/ijcpr

\section{INTRODUCTION}

Breast cancer is the second most cancer in the whole world. About 1 in 8 women (about 12\%) in the United States has breast cancer, 232,670 new cases in women and 2,360 new cases in men per year [1].

Brain metastases are found in about $10-16 \%$ of patients with breast cancer and have poor survival [2]. The main therapeutic modality for breast cancer with brain metastasis is radiation. Whole Brain Radiotherapy (WBRT) with a dose of 150-400cGy per day with a total dose, reaching 3000-5000cGy provides an adequate dose of tumor [3].

Several studies have shown that the combination of chemotherapy and radiation can increase survival for 3-6 mo [4]. Capecitabine was found to be effective for use in breast cancer with metastasis [5]. Some studies say a limited amount of capecitabine, and its metabolites cross the BBB in animal models [6].

There are no studies in Indonesia that have analyzed both the role of whole-brain radiation and the administration of capecitabine to breast cancer patients with brain metastases. This study aims to determine the effectiveness of WBRT on the response of breast cancer brain metastatic lesions by Capecitabine administration.

\section{MATERIALS AND METHODS}

This study uses a prospective, randomized-blind, cohort analytic study approach. Samples were patients with brain metastasis and a history of previous breast malignancies who would undergo WBRT+capecitabine in MurniTeguh Hospital from January 2019 to August 2019, which met the inclusion and exclusion criteria. Patients with visceral metastasis $>2$, have other primary malignancies, are unwilling to participate in the study, have leptomeningeal or intra-tumoral bleeding, get hormonal therapy or Her2 for breast cancer, get less radiation than planned, and patients who take Capecitabine irregularly and patients with cystic lesions excluded from this study.

Subjects were randomized into two groups by giving different fraction WBRT and capecitabine. Group, I was the subject who received WBRT 10x3Gy and capecitabine $1000 \mathrm{mg} / \mathrm{m}^{2} /$ b.i.d., Group II were subjects who received WBRT 20X2 Gy+capecitabine $1000 \mathrm{mg} / \mathrm{m}^{2} /$ b.i.d. . The subjects were then evaluated $4 \mathrm{w}$ postradiation by CT scan and MRI brain examination by contrast. The measurement results are divided into two, namely a value of 1 if a complete response is found (loss of all intra-cranial lesion targets with no evidence of tumor anywhere) or a partial response (at least a reduction of at least $30 \%$ of all tumor measurements), and a value of 0 if not there is a response (stable or progressive). Data on differences in patient responses in the two treatment groups were analyzed with the SPSS program. The dependent variable is categorized as Responsder (CR+PR) and Non-Responsder (SD+PD). Analysis of differences in respondent characteristics and responses of brain metastatic breast cancer patients receiving WBRT and capecitabine combination therapy was performed using the Chi-square test if the data were normally distributed or Fischer exact if the data were not normally distributed. A P value of difference $<0.05$ was considered significant.

\section{RESULTS}

A total of 23 breast cancer patients with brain metastasis participated in this study. Subjects were divided into two groups. Group 1 were 11 subjects and group 2 were 12 subjects, in which group 1 treatment was $10 \times 3 G y+$ capecitabine and group 2 was 20x2Gy+capecitabine. 
Table 1: Characteristics of subjects

\begin{tabular}{|c|c|c|c|c|c|c|c|c|}
\hline & & \multicolumn{2}{|c|}{ Group 1 (10 X 3 Gy) } & \multicolumn{2}{|c|}{ Group 2 (20 X 2 Gy) } & \multicolumn{2}{|c|}{ Total } & \multirow[t]{2}{*}{ P value* } \\
\hline & & $\mathbf{n}$ & $\%$ & n & $\%$ & $\mathbf{n}$ & $\%$ & \\
\hline \multirow[t]{3}{*}{ Age } & $<50$ & 5 & 38.5 & 8 & 61.5 & 13 & 100 & 0.414 \\
\hline & $\geq 50$ & 6 & 60 & 4 & 40 & 10 & 100 & \\
\hline & Total & 11 & 47.8 & 12 & 52.2 & 23 & 100 & \\
\hline \multirow[t]{6}{*}{ Ethnic } & Batak & 3 & 37.5 & 5 & 62.5 & 8 & 100 & \\
\hline & Aceh & 3 & 60 & 2 & 40 & 5 & 100 & 0.581 \\
\hline & Java & 2 & 40 & 3 & 60 & 5 & 100 & \\
\hline & Chineese & 3 & 75 & 1 & 25 & 4 & 100 & \\
\hline & Malay & 0 & 0 & 1 & 100 & 1 & 100 & \\
\hline & Total & 11 & 47.8 & 12 & 52.2 & 23 & 100 & \\
\hline \multirow[t]{6}{*}{ Education } & Elementary & 3 & 75 & 1 & 25 & 4 & 100 & 0.423 \\
\hline & Junior high school & 1 & 20 & 4 & 80 & 5 & 100 & \\
\hline & Senior high school & 5 & 55.6 & 4 & 44.4 & 9 & 100 & \\
\hline & Diploma & 0 & 0 & 1 & 100 & 1 & 100 & \\
\hline & Bachelor & 2 & 50 & 2 & 50 & 4 & 100 & \\
\hline & Total & 11 & 47.8 & 12 & 52.2 & 23 & 100 & \\
\hline \multirow[t]{4}{*}{ Occupation } & Housewife & 6 & 42.9 & 8 & 57.1 & 14 & 100 & 0.486 \\
\hline & Private employee & 2 & 40 & 3 & 60 & 5 & 100 & \\
\hline & Entrepreneur & 3 & 75 & 1 & 25 & 4 & 100 & \\
\hline & Total & 11 & 47.8 & 12 & 52.2 & 23 & 100 & \\
\hline \multirow[t]{3}{*}{ Menstrual Status } & Pre-Menopause & 5 & 35.7 & 9 & 64.3 & 14 & 100 & 0.214 \\
\hline & Menopause & 6 & 66.7 & 3 & 33.3 & 9 & 100 & \\
\hline & Total & 11 & 47.8 & 12 & 52.2 & 23 & 100 & \\
\hline \multirow[t]{3}{*}{ Overall Treatment Time } & $12-14 \mathrm{~d}$ & 0 & 0 & 12 & 100 & 12 & 100 & $<0.001$ \\
\hline & $26-31 \mathrm{~d}$ & 11 & 100 & 0 & 0 & 11 & 100 & \\
\hline & Total & 11 & 47.8 & 12 & 52.2 & 23 & 100 & \\
\hline \multirow[t]{3}{*}{ KPS } & $<70$ & 6 & 75 & 2 & 25 & 8 & 100 & 0.089 \\
\hline & $\geq 70$ & 5 & 33.7 & 10 & 66.7 & 15 & 100 & \\
\hline & Total & 12 & 52.2 & 12 & 52.2 & 23 & 100 & \\
\hline Lesions & $\leq 3$ & 4 & 30.8 & 9 & 69.2 & 13 & 100 & 0.1 \\
\hline & $>3$ & 7 & 70 & 3 & 30 & 10 & 100 & \\
\hline & Total & 11 & 47.8 & 12 & 52.2 & 23 & 100 & \\
\hline $\mathrm{Hb}$ & $<10$ & 0 & 0 & 0 & 0 & 0 & 0 &.$^{\mathrm{a}}$ \\
\hline & $\geq 10$ & 11 & 47.8 & 12 & 52.2 & 23 & 100 & \\
\hline & Total & 11 & 47.8 & 12 & 52.2 & 23 & 100 & \\
\hline Leukocyte & $<3,600 / \mu \mathrm{l}$ & 0 & 0 & 0 & 0 & 0 & 0 & 0.069 \\
\hline & $3,600-11,000 / \mu \mathrm{l}$ & 6 & 35.3 & 11 & 64.7 & 17 & 100 & \\
\hline & $>11.000 / \mu \mathrm{l}$ & 5 & 83.3 & 1 & 16.7 & 6 & 100 & \\
\hline & Total & 11 & 47.8 & 12 & 52.2 & 23 & 100 & \\
\hline Thrombocyte & $<150,000 / \mu \mathrm{l}$ & 0 & 0 & 0 & 0 & 0 & 0 &.$^{\mathrm{a}}$ \\
\hline & $150,000-450,000 / \mu \mathrm{l}$ & 11 & 47.8 & 12 & 52.2 & 23 & 100 & \\
\hline & $>450,000 / \mu \mathrm{l}$ & 0 & 0 & 0 & 0 & 0 & 0 & \\
\hline & Total & 11 & 47.8 & 12 & 52.2 & 23 & 100 & \\
\hline AST & $\leq 45 \mu / 1$ & 9 & 42.9 & 12 & 57.1 & 21 & 100 & 0.217 \\
\hline & $>45 \mu / 1$ & 3 & 100 & 3 & 100 & 3 & 100 & \\
\hline & Total & 11 & 47.8 & 12 & 52.2 & 23 & 100 & \\
\hline ALT & $\leq 35 \mu / 1$ & 5 & 45.5 & 6 & 54.5 & 11 & 100 & 1 \\
\hline & $>35 \mu / 1$ & 6 & 50 & 6 & 50 & 12 & 100 & \\
\hline & Total & 11 & 47.8 & 12 & 52.2 & 23 & 100 & \\
\hline Ur & $<13 \mathrm{mg} / \mathrm{dl}$ & 1 & 100 & 0 & 0 & 1 & 100 & 0.478 \\
\hline & $13-43 \mathrm{mg} / \mathrm{dl}$ & 10 & 45.5 & 12 & 54.5 & 22 & 100 & \\
\hline & $>43 \mathrm{mg} / \mathrm{dl}$ & 0 & 0 & 0 & 0 & 0 & 0 & \\
\hline & Total & 11 & 47.8 & 12 & 52.2 & 23 & 100 & \\
\hline $\mathrm{Cr}$ & $<0.50 \mathrm{mg} / \mathrm{dl}$ & 0 & 0 & 0 & 0 & 0 & 0 & 0.069 \\
\hline & $0.50-0.90 \mathrm{mg} / \mathrm{dl}$ & 10 & 62.5 & 6 & 37.5 & 16 & 100 & \\
\hline & $>0.90 \mathrm{mg} / \mathrm{dl}$ & 1 & 14.3 & 6 & 85.7 & 7 & 100 & \\
\hline & Total & 11 & 47.8 & 12 & 52.2 & 23 & 100 & \\
\hline PA & Invasive Ductal Ca & 11 & 47.8 & 12 & 52.2 & 23 & 100 & $\mathrm{a}^{\mathrm{a}}$ \\
\hline & Invasive Lobular Ca & 0 & 0 & 0 & 0 & 0 & 0 & \\
\hline & Total & 11 & 47.8 & 12 & 52.2 & 23 & 100 & \\
\hline IHK & ER+, PR+, HER2- & 1 & 50 & 1 & 50 & 2 & 100 & 0.392 \\
\hline & $\mathrm{ER}+, \mathrm{PR}+, \mathrm{HER} 2+$ & 0 & 0 & 3 & 100 & 3 & 100 & \\
\hline & ER-, PR-, HER2+ & 4 & 57.1 & 3 & 42.9 & 7 & 100 & \\
\hline & ER-, PR-, HER2- & 1 & 100 & 0 & 0 & 1 & 100 & \\
\hline & No examination & 5 & 50 & 5 & 50 & 10 & 100 & \\
\hline & Total & 11 & 50 & 11 & 50 & 22 & 100 & \\
\hline
\end{tabular}

Based on the characteristics of the research subjects, the variables of age, ethnicity, education, occupation and menstrual status showed homogeneous results in both groups. Other variables such as KPS, lesions, hemoglobin, leukocytes, platelets, AST, ALT, Creatinine, Ureum, PA, and IHK also showed homogeneous results. Overall Treatment Time (OTT) and $\mathrm{Cr}$ 
value data showed significant differences between the two groups, which found OTT for $12-14 \mathrm{~d}$ of 11 subjects $(100 \%)$ in group 1 and OTT for $26-31 \mathrm{~d}$ of 12 subjects (100\%) in group 2 (p
$=<0.001)$. And also found $\mathrm{Cr}<0.50 \mathrm{mg} / \mathrm{dl}$ of 2 subjects $(100 \%)$ in group 1 and $\mathrm{Cr}>0.90 \mathrm{mg} / \mathrm{dl}$ of 6 subjects $(100 \%)$ in group 2 ( $\mathrm{p}=$ $0.01)$.

Table 2: The correlation between subject characteristic and therapeutics response

\begin{tabular}{|c|c|c|c|c|c|c|c|c|}
\hline & & \multicolumn{2}{|c|}{ Responder } & \multicolumn{2}{|c|}{ Non-Responder } & \multicolumn{2}{|c|}{ Total } & \multirow[t]{2}{*}{ P value* } \\
\hline & & $\mathbf{n}$ & $\%$ & $\mathbf{n}$ & $\%$ & $\mathbf{n}$ & $\%$ & \\
\hline \multirow[t]{3}{*}{ Age } & $<50$ & 9 & 69.2 & 4 & 30.8 & 13 & 100 & 1 \\
\hline & $\geq 50$ & 7 & 70 & 3 & 30 & 10 & 100 & \\
\hline & Total & 16 & 69.6 & 7 & 30.4 & 23 & 100 & \\
\hline \multirow[t]{6}{*}{ Ethnic } & Batak & 7 & 87.5 & 1 & 12.5 & 8 & 100 & \\
\hline & Aceh & 3 & 60 & 2 & 40 & 5 & 100 & 0.590 \\
\hline & Java & 3 & 60 & 2 & 40 & 5 & 100 & \\
\hline & Chineese & 2 & 50 & 2 & 50 & 4 & 100 & \\
\hline & Malay & 1 & 100 & 0 & 0 & 1 & 100 & \\
\hline & Total & 16 & 69.6 & 7 & 30.4 & 23 & 100 & \\
\hline \multirow[t]{6}{*}{ Education } & Elementary & 3 & 75 & 1 & 25 & 4 & 100 & \\
\hline & Junior high school & 3 & 60 & 2 & 40 & 5 & 100 & 0.938 \\
\hline & Senior high school & 6 & 66.7 & 3 & 33.3 & 9 & 100 & \\
\hline & Diploma & 1 & 100 & 0 & 0 & 1 & 100 & \\
\hline & Bachelor & 3 & 75 & 1 & 25 & 4 & 100 & \\
\hline & Total & 16 & 69.6 & 7 & 30.4 & 23 & 100 & \\
\hline \multirow[t]{4}{*}{ Occupation } & Housewife & 10 & 71.4 & 4 & 28.6 & 14 & 100 & \\
\hline & Private employee & 4 & 80 & 1 & 20 & 5 & 100 & 0.606 \\
\hline & Entrepreneur & 2 & 50 & 2 & 50 & 4 & 100 & \\
\hline & Total & 16 & 69.6 & 7 & 30.4 & 23 & 100 & \\
\hline \multirow[t]{3}{*}{ Menstrual Status } & Pre-Menopause & 13 & 92.9 & 1 & 7.1 & 14 & 100 & \\
\hline & Menopause & 3 & 33.3 & 6 & 66.7 & 9 & 100 & 0.005 \\
\hline & Total & 16 & 69.6 & 7 & 30.4 & 23 & 100 & \\
\hline \multirow[t]{3}{*}{ Overall Treatment Time } & $12-14 \mathrm{~d}$ & 11 & 91.7 & 1 & 8.3 & 12 & 100 & 0.027 \\
\hline & $26-31 d$ & 5 & 45.5 & 6 & 54.5 & 11 & 100 & \\
\hline & Total & 16 & 69.6 & 7 & 30.4 & 23 & 100 & \\
\hline \multirow[t]{3}{*}{ KPS } & $<70$ & 6 & 75 & 2 & 25 & 8 & 100 & \\
\hline & $\geq 70$ & 10 & 66.7 & 5 & 33.3 & 15 & 100 & 1 \\
\hline & Total & 16 & 69.6 & 7 & 30.4 & 23 & 100 & \\
\hline Lesions & $\leq 3$ & 12 & 92.3 & 1 & 7.7 & 13 & 100 & \\
\hline & $>3$ & 4 & 40 & 6 & 60 & 10 & 100 & 0.019 \\
\hline & Total & 16 & 69.6 & 7 & 30.4 & 23 & 100 & \\
\hline $\mathrm{Hb}$ & $<10$ & 0 & 0 & 0 & 0 & 0 & 0 & \\
\hline & $\geq 10$ & 16 & 69.6 & 7 & 30.4 & 23 & 100 &.$^{\mathrm{a}}$ \\
\hline & Total & 16 & 69.6 & 7 & 30.4 & 23 & 100 & \\
\hline Leukocyte & $<3,600 / \mu \mathrm{l}$ & 0 & 0 & 0 & 0 & 0 & 0 & \\
\hline & $3,600-11,000 / \mu \mathrm{l}$ & 13 & 76.5 & 4 & 23.5 & 17 & 100 & 0.318 \\
\hline & $>11.000 / \mu \mathrm{l}$ & 3 & 50 & 3 & 50 & 6 & 100 & \\
\hline & Total & 16 & 69.6 & 7 & 30.4 & 23 & 100 & \\
\hline Thrombocyte & $<150,000 / \mu \mathrm{l}$ & 0 & 0 & 0 & 0 & 0 & 0 &.$^{\mathrm{a}}$ \\
\hline & $150,000-450,000 / \mu \mathrm{l}$ & 16 & 69.9 & 6 & 30.4 & 23 & 100 & \\
\hline & $>450,000 / \mu \mathrm{l}$ & 0 & 0 & 0 & 0 & 0 & 0 & \\
\hline & Total & 16 & 69.6 & 7 & 30.4 & 23 & 100 & \\
\hline AST & $\leq 45 \mu / 1$ & 15 & 71.4 & 6 & 28.6 & 21 & 100 & \\
\hline & $>45 \mu / 1$ & 1 & 50 & 1 & 50 & 2 & 100 & 0.526 \\
\hline & Total & 16 & 69.6 & 7 & 30.4 & 23 & 100 & \\
\hline ALT & $\leq 35 \mu / 1$ & 7 & 63.6 & 4 & 36.4 & 11 & 100 & \\
\hline & $>35 \mu / 1$ & 9 & 75 & 3 & 25 & 12 & 100 & 0.667 \\
\hline & Total & 16 & 69.6 & 7 & 30.4 & 23 & 100 & \\
\hline Ur & $<13 \mathrm{mg} / \mathrm{dl}$ & 0 & 0 & 1 & 100 & 1 & 100 & \\
\hline & $13-43 \mathrm{mg} / \mathrm{dl}$ & 16 & 72.7 & 6 & 27.3 & 22 & 100 & 0.304 \\
\hline & $>43 \mathrm{mg} / \mathrm{dl}$ & 0 & 0 & 0 & 0 & 0 & 0 & \\
\hline & Total & 16 & 69.6 & 7 & 30.4 & 23 & 100 & \\
\hline $\mathrm{Cr}$ & $<0.50 \mathrm{mg} / \mathrm{dl}$ & 0 & 0 & 0 & 0 & 0 & 0 & \\
\hline & $0.50-0.90 \mathrm{mg} / \mathrm{dl}$ & 10 & 62.5 & 6 & 37.5 & 16 & 100 & 0.366 \\
\hline & $>0.90 \mathrm{mg} / \mathrm{dl}$ & 6 & 85.7 & 1 & 14.3 & 7 & 100 & \\
\hline & Total & 16 & 69.6 & 7 & 30.4 & 23 & 100 & \\
\hline PA & Invasive Ductal Ca & 16 & 69.6 & 7 & 30.4 & 23 & 100 & \\
\hline & Invasive Lobular $\mathrm{Ca}$ & 0 & 0 & 0 & 0 & 0 & 0 &.$^{\mathrm{a}}$ \\
\hline & Total & 16 & 69.6 & 7 & 30.4 & 23 & 100 & \\
\hline IHK & $\mathrm{ER}+, \mathrm{PR}+, \mathrm{HER} 2-$ & 2 & 100 & 0 & 0 & 2 & 100 & \\
\hline & $\mathrm{ER}+, \mathrm{PR}+, \mathrm{HER} 2+$ & 2 & 66.7 & 1 & 33.3 & 3 & 100 & 0.346 \\
\hline & ER-, PR-, HER2+ & 6 & 85.7 & 1 & 14.3 & 7 & 100 & \\
\hline & ER-, PR-, HER2- & 0 & 0 & 1 & 100 & 1 & 100 & \\
\hline & No examination & 6 & 60 & 4 & 40 & 10 & 100 & \\
\hline & Total & 16 & 69.6 & 7 & 30.4 & 23 & 100 & \\
\hline
\end{tabular}


The characteristics of the research subjects, the variables of age, ethnicity, education, occupation, KPS and lesions showed no significant correlation to therapeutic response. Other variables such as hemoglobin, leukocytes, platelets, AST, ALT, Creatinine, Ureum, PA, and IHK also showed also no significant correlation to therapeutic response. The characteristics that shown significant correlation were Menstrual Status, OTT and Lesions.

Table 3: The result of response

\begin{tabular}{|c|c|c|c|c|c|c|c|}
\hline & \multicolumn{2}{|c|}{ Responder } & \multicolumn{2}{|c|}{ Non-Responder } & \multicolumn{2}{|c|}{ Total } & \multirow[t]{2}{*}{ P value* } \\
\hline & $\mathbf{n}$ & $\%$ & $\mathbf{n}$ & $\%$ & $\mathbf{n}$ & $\%$ & \\
\hline Group 1 & 5 & 45.5 & 6 & 54.5 & 11 & 100 & \\
\hline Group 2 & 11 & 91.7 & 1 & 8.3 & 12 & 100 & 0.027 \\
\hline Total & 16 & 69.6 & 6 & 30.4 & 23 & 100 & \\
\hline
\end{tabular}

The results of responses to WBRT and capecitabine showed significant differences between groups. Group I (WBRT 10x3Gy + capecitabine 1000 $\mathrm{mg} / \mathrm{m}^{2} /$ b.i.d) obtained results of $5(45.5 \%)$ responding to therapy. Whereas ingroup II (WBRT $20 \mathrm{x} 2 \mathrm{~Gy}+$ capecitabine $\left.1000 \mathrm{mg} / \mathrm{m} 2 / \mathrm{b} . \mathrm{i} . \mathrm{d}\right)$ found 11 $(91.7 \%)$ patients responded to therapy. The results of statistical analysis showed that there were significant differences between the two groups with a value of $\mathrm{P}=0.027$

\section{DISCUSSION}

\section{Subject characteristics}

Brain metastatic breast cancer can occur in women of all ages. In this study, the highest number of subjects was found in the age range $<50$ y. This is consistent with research conducted by Chargari, in 2009 where the average age of the most frequently found was 38-53 y.

\section{Response to WBRT+capecitabine}

In this study, there were more respondents in group 2, WBRT 20x2Gy+ capecitabine with 12 subjects (91.7\%). Clinically, there are more respondents in group 2. By giving WBRT 20x, then the dose of capecitabine will also increase. As capecitabine is increased, the radio sensitizer effect will also increase during WBRT. In a study conducted by Cyrus, in 2009 by giving 10X3Gy+capecitabine, $1000 \mathrm{mg} / \mathrm{m}^{2}$ obtained $60 \%$ responder results. WBRT 20x2Gy is well tolerated and considered in patients with $\mathrm{SPK} \geq 70$ with solitary or multiple lesions; this was stated in a study conducted by Noordijk et al., In 1994.

In this study, statistically, the results were obtained $p=0.027$, in which there was a response relationship between the groups and WBRT+capecitabine.

\section{Factors that affect the study}

There are many factors that affect this study, one of which is the time of the study. The duration of the study was also influenced by several factors, such as rare cases such as breast cancer with brain metastases. Also, the issue of subject availability agreed to therapy, such as socioeconomic problems in patients. Because most patients come from out of town and are required to stay near the hospital during therapy. Patients must find a place to stay and eat alone. Another factor is family support, because it is far from the place of origin, so support from the family is also very little.

The availability of resources in Indonesia is also very limited, where the LINAC devices that can use SRS or SRT technique are also limited. Because of this limitation, this study uses WBRT.

The dose of the capecitabine used is $1000 \mathrm{mg} / \mathrm{m}^{2} / \mathrm{b}$.i.d because the drug preparations in Indonesia are only $500 \mathrm{mg}$ per tablet. Abroad, there are 2 preparations of Capecitabine, namely $500 \mathrm{mg} / \mathrm{tab}$ and $150 \mathrm{mg} / \mathrm{tab}$.

\section{ACKNOWLEDGMENT}

Further research is expected to be carried out to assess survival rates and the relationship of therapeutic response to survival rates. In addition, it is recommended to provide $500 \mathrm{mg} / \mathrm{tab}$ and 150 $\mathrm{mg} /$ tab capecitabine preparation and LINAC devices that can-do the SRS technique in Indonesia.

\section{FUNDING}

Nil

\section{AUTHORS CONTRIBUTIONS}

All the authors have contributed equally.

\section{CONCLUSION}

In this study, the administration of capecitabine and $20 \times 2$ gy fractions gave a better response both clinically and statistically ( $\mathrm{p}=$ 0.027).

\section{REFERENCES}

1. American Cancer Society. Cancer Treatment and Survivorship Facts and Figures; 2014.

2. Lu J, Steeg PS, Price JE. Breast cancer metastasis: challenges and opportunities. Cancer Res 2009;69:4951-3.

3. Devita H, Rosenbergs. Brain Metastasis. Cancer principles and practice of oncology. $9^{\text {th }}$ edition. Lippincott Williams and Wilkins; 2011.

4. Patchell RA, Regine WF. Brain Metastase: Whole Brain Radiation Therapy Perspective. Principles and Practice of Stereotactic Radiosurgery; 2008. p. 201-5.

5. Rivera E, Meyers C, Groves M. Phase I study of capecitabine in combination with temozolomide in the treatment of patients with brain metastases from breast carcinoma. Cancer 2006;107:134854.

6. McEvoy GK. editor. Capecitabine. In: AHFS drug information. Bethesda MD: American Society of Health-System Pharmacists; 2002. p. 916-21. 